\title{
MARIA DA GRAÇA FERREIRA PASSOU, DEIXOU MARCAS E PARTIU
}

Quem diria que aos 31 anos de idade, Maria da Graça Ferreira, cheia de energia, vigor, reveladora de uma disposição ímpar, viria a ser colhida tão surpreendentemente do seio da sua família, da família universitária e dos seus amigos? De facto, é-nos velado o "dia e a hora" e, quando somos chamados com maior ou menor violência, deixamos tudo e todos; é uma partida que não contempla adiamentos, tornando-se irreversível. Os projectos que temos em vista realizar terminam. Assim foi para a Maria da Graça. Nós, com maior ou menor coragem, recordamos a sua presença que tanta alegria e serenidade irradiava nos ambientes onde porventura estivesse, contagiando ainda todos os que tinham o privilégio de gozar mais de perto da sua companhia.

Estas simples e breves palavras querem ser essencialmente de agradecimento e louvor pela vida de Maria da Graça. Quantitativamente, não foram muitos os anos de convívio, apenas 11, mas foram muito bem preenchidos. A Maria da Graça passou intensamente pela nossa vida, de 1986 a 1991, como aluna. Logo no primeiro ano do seu curso, não foi difícil para nós entender quem era a Maria da Graça Ferreira e quem viria a ser sucessivamente. Não nos enganámos. Orgulhamo-nos, com grande carinho, pelo facto de a termos tido como aluna. Aluna exemplar, ambiciosa, no sentido de querer mais e sempre melhor, descontente com as passividades e a falta de interesse, enfrentava os professores com espírito maduro, aberto e colaborante. A partir de 1991, como Colega de serviço na nossa querida e estimada Universidade Católica em Viseu, onde trabalhámos muito em união, sempre se manifestou disponível para quem precisasse da sua ajuda, não se poupando a sacrifícios, o que ninguém pode deixar de reconhecer. Se o fizéssemos estaríamos a cometer uma grande injustiça para com a Graça. Como Amiga, foi aquilo que nós já então prevíamos. Queremos continuar a manifestar-lhe a nossa grande estima e a dizer-lhe, onde ela estiver, que a sua presença continua bem viva na nossa memória, como aluna, colega e amiga.

A Maria da Graça abraçava o trabalho com extrema dignidade e competência, prescindia dos interesses pessoais em favor dos aspectos profissionais, da Universidade, dos amigos e dos alunos, a quem se dava sem peso nem medida. Sem- 
pre atenta às necessidades dos outros. Caminhava com os cansados, surpreendia toda a gente pela sua capacidade de trabalho organizado, pela simpatia e boa disposição que apresentava todos os dias e que distribuía a todos os que com ela trabalhavam e conviviam. Ao pé da Maria da Graça ninguém podia estar triste, mesmo que ela estivesse menos bem, aparecia sempre aos outros bem disposta, animando os mais pessimistas.

A Maria da Graça envolvia-se sempre em causas fundamentais e por isso tinha tanta popularidade. Esta virtude era apreciada e sentida por todos quantos a conheciam. Não foi por acaso que muitas instituições e pessoas - Câmara Municipal de Viseu, Governo Civil, Empresas, com as quais mantinha colaboração, a Universidade, a Associação Académica, que decretou luto académico durante dois dias, colegas de curso, alunos, jornais e muitos anónimos - Ihe prestaram homenagem.

O relacionar-se e a comunicação eram para a Graça a forma de ultrapassar discórdias. Dizia muitas vezes: "falar ajuda a resolver os problemas, as coisas têm de ser esclarecidas". Outras referia: "o silêncio e a falta de diálogo matam a união e a confiança entre as pessoas"; "é a falar que se aclaram mal-entendidos, dúvidas e se eliminam as desavenças". A sua presença forte e segura no meio de nós manifestava-se nesta vontade autêntica que transmitia.

A Maria da Graça punha muita paixão e empenhava-se cem por cento naquilo que fazia. Não buscava soluções das mais fáceis para resolver os problemas, mas buscava as mais justas e capazes de os sanar e objectivamente tentava que esses não existissem. Mesmo no meio da agitação conseguia encarar tudo com um sorriso e, embora não tendo grande voz para cantar, os seus lábios pronunciavam uma música que nem sempre comunicava as mesmas melodias, mas a sua inteligência permitia- The a descodificação e adaptava-a às circunstâncias do momento, não deixando escapar a ocasião, empenhava-se e fazia com que os outros também o fizessem. Evitava as situações menos boas e potenciava sempre as melhores. Manifestava sensibilidade ao humor operante, o que não é nada fácil.

A Maria da Graça era dada a poucas hesitações. Convicta, depressa tomava o gosto por aquilo que gostava e queria fazer, encontrando aí coragem para novos desafios, não trocando qualidade por quantidade. Vivia apaixonada com conviç̧ões fixas e lutava sempre por essas convicções. Era objectiva nas suas posições, defendia-se sempre com factos concretos e não em utopias ou extrapolações subjectivas sem fundamento; as suas ideias consubstanciavam-se sempre em fazer mais e melhor.

A Maria da Graça era detentora de uma personalidade forte, determinada e, por isso, pautava-se sempre por valorizar op̧̧ões sinceras, justas e verdadeiras, sobrepondo a verdade à hipocrisia e à mentira, valores tão sublimes e tão difíceis de introduzir na vida moderna, onde o individualismo e o comodismo procuram suplantar e esquecer que eles são a melhor opção para a convivência humana. Não há meias medidas, aquelas ou se possuem ou não, e a Maria da Graça era assim, lutava pela sua preservação. 
Por tudo isto e muito mais, os laços de amizade que nos uniam podem, neste momento, deixar transparecer alguma emotividade e sensibilidade, susceptíveis de parecer algo exageradas mas, de facto, não conseguimos abstrair-nos daquilo que foi a nossa vida conjunta. Discórdias, opiniões diferentes também existiram, mal se assim não fosse, não somos iguais, não somos santas, mas, nos momentos da discussão procurávamos o consenso, nem que fosse preciso adiar para o dia seguinte a decisão; era necessário ver o que era melhor para solucionar a questão e ultrapassar a visão individual. Mas, principalmente nos momentos de tristeza mas também de alegrias, e que foram muitos, recordamos sempre os dias que vivemos juntas.

Cinco meses já volvidos após a sua morte, torna-se difícil digerir a sua ausência. A Maria da Graça partiu, mas em nós ficou a saudade. Temos dificuldade em entender e, mesmo para quem tem fé e acredita que o momento de separação é também de esperança, não deixa, no entanto, de ser também de dor. A Graça, depois de ter sofrido um pouco, e dizemos um pouco porque partiu cedo, muito cedo, ainda tinha muito que fazer... era demasiado nova, tinha apenas 31 anos. Nós queríamos que continuasse a trabalhar, a brincar, a passear connosco... A sua ausência física cria em nós momentos de recordações, de saudade.

Perante este acontecimento, somos levados a olhar a vida, a reflectir e, se fôssemos capazes de contar a sua vivência iríamos longe, muito, muito longe. Fisicamente perdemos a Graça, mas a sua presença continua muito viva, mas de modo diferente, as vozes não se ouvem do mesmo modo, são muito lentas, mais calmas e tranquilas, mas soam forte no meiọ da tristeza, aquilo que ela não queria para ninguém.

A Maria da Graça era igual a si própria, mesmo que isso lhe custasse e fizesse sofrer muito, mas foi por isso que gostámos dela e a admirámos. Há saudades muito marcadas, concretizadas pelo convívio e por uma sã amizade e confiança mútua, mesmo quando estávamos em desacordo.

A presença do seu entusiasmo, da sua alegria, bastava para conquistar optimismos. Não se acomodava, trabalhava com persistência, ajudava, animava e fazia dos outros persistentes. Mesmo no fim de um dia de trabalho exausto, regressava a casa, o trabalho não parava por muito tempo. Quando o cansaço do computador, da leitura que procurava sempre actualizar, da preparação de aulas, etc., a dominava, dizia: "vou fazer um pouco de renda sentada no sofá para descansar um pouco e depois recomeçar". A mãe dizia-lhe: "filha não trabalhes tanto, estás cansada"; mas isso era coisa que a Graça não queria ouvir. Hoje, quando passamos um pouco com a mãe e lhe dizemos, temos que ir embora, precisamos ainda de ir trabalhar, são compreensíveis as suas palavras: "Não trabalhe tanto, não viu a minha filha que trabalhava tanto, estava sempre preocupada com o trabalho e morreu tão cedo, já não trabalha mais, já não faz mais cursos já não faz mais nada".

Graça! - Ainda precisávamos de ti, tinhas muito que fazer, mas valeu a pena teres vivido, mesmo durante pouco tempo fizeste muito bem, deixaste-nos muitas saudades, continua connosco, e acredita que nós continuamos contigo. 